\title{
Adaptive Sustainable Reuse for Cultural Heritage: A Multiple Criteria Decision Aiding Approach Supporting Urban Development Processes
}

\author{
Lucia Della Spina \\ Department of Heritage, Architecture and Urban Planning, Mediterranea University of Reggio Calabria, \\ 89125 Reggio Calabria (RC), Italy; lucia.dellaspina@unirc.it
}

Received: 20 December 2019; Accepted: 5 February 2020; Published: 13 February 2020

\begin{abstract}
The European Union identifies the cultural heritage of cities as the main driver of development strategies. From this perspective, adaptive reuse can play a decisive role not only in terms of increasing the life cycle of the heritage but also as an urban strategy capable of generating new economic, cultural, and social values, thus supporting innovative dynamics of local development. The aim is to propose an integrated evaluation model based on the combined use of multi-criteria techniques, which helps to classify adaptive reuse strategies of unused cultural heritage assets and supports decision-makers in the implementation of development strategies in vulnerable contexts. The case study focuses on the potential reuse of some historical fortifications located along the coasts of the Strait of Messina in Southern Italy. The results obtained show that the proposed model can be a useful decision support tool, in contexts characterized by high complexity, able to guarantee the transparency of the decision-making process, and in which it is necessary to highlight the elements that influence the dynamics of the choice for the construction of shared development strategies.
\end{abstract}

Keywords: cultural heritage conservation; adaptive reuse; multi-criteria decision aid; strategic assessment

\section{Introduction and Overview}

In the current scientific debate, cities represent the contexts in which resources, capital, skills, and talents are concentrated and, at the same time, places where many challenges are concentrated regarding environmental (pollution, waste, climate change), economic (unemployment, social exclusion, well-being), political (instability in governance processes, lack of strategic planning), and cultural (training, creativity and innovation) dimensions. The city, therefore, allows to experiment the paradigm shift from linear economy to circular economy, in which to promote synergetic, fair and inclusive processes capable of activating new forms of urban productivity and social and economic innovation.

In particular, the European Commission identifies the cultural heritage of cities as the main driver of development and supports strategies in which it is considered one of the fundamental elements of possible transformations, which can be activated through mixed top down/bottom up approaches in the short and long term. From this perspective, adaptive reuse can play a decisive role not only in terms of increasing the life cycle of the heritage but also as an urban strategy capable of generating new, even divergent values (economic, aesthetic, cultural, educational, political), supporting innovative dynamics of local development and which underline the importance of preserving cultural heritage and the instrumental values for its livelihood [1] in a "circular" perspective [2]. In fact, if you look at cultural heritage as a potential element of an "self-sustainability" territorial system [3], which continually redefines itself and sustains and reproduces itself from within, it is possible to identify the re-use of cultural heritage as an essential contribution in the realization of a model of economy and of "circular" cities and territories, capable of eliminating the waste of environmental resources (soils, materials, 
energy, etc.) and cultural resources (tangible and intangible heritage, knowledge, etc.), and capable of transforming "waste" into new economic, environmental, cultural, and social resources.

Cultural heritage, in fact, can be considered not only a legacy to be handed down to posterity but also a central resource for triggering processes of local and global development. At the moment, however, the conservation and enhancement of the heritage that has a cultural and landscape value represent a burden for the community. However, the inequality between the quantity of material and cultural heritage available and the increasingly limited availability of public resources for conservation have led to the total or partial abandonment of cultural heritage. Even where conservation measures are carried out, the potential impact of this public investment is countered by an absent or short-sighted management program.

Today, in the field of reusing historical heritage, scientific research has developed methods to assess the compatibility of new functions with the morphological and dimensional characteristics of existing buildings and with the objectives of urban development and revitalization [4-6]. In the planning and technical and economic feasibility study phase, the purpose of these methods is to determine the most compatible use. In the planning phase, the compatibility assessment allows decision-makers to identify new appropriate uses, compatible with the layout and the original meaning of buildings and historic places, a new use that will bring benefits such as the improvement of the building, market value, use, environmental, cultural and social value [5,7]. The desire to protect the identity of a historic building leads planners to estimate the quantity and amount of transformations required by each function in order to find the most compatible solution. However, the choice of the new function must also take into account the economic and social objectives and the effects of reuse on the urban environment.

The lack of public resources has, in fact, pushed many local administrations to favor new forms of enhancement of public buildings in able to promote the "adaptive reuse" of a historic building in order to preserve its social, historical, and cultural values but also to stimulate the experimentation of new circular businesses, financing and governance models in heritage conservation, creating synergies between multiple actors, and reducing the use of resources and regenerating values, capital, and knowledge

Decisions on the increasingly scarce allocation of public resources for the conservation or development of cultural heritage are based on a series of multiple and heterogeneous criteria, which are often in conflict, as well as on the preferences of various stakeholder. In this context, multi-criteria approaches provide an adequate theoretical and methodological framework to deal with the complexity that characterizes the adaptive reuse strategies of cultural heritage.

In the literature, many multi-criteria methods have been developed in recent decades [8] with applications to real cases (including examples of reuse) and in different sectors to support decision-making processes [9]. "Multi-criteria analyses" are very useful tools in the ex-ante evaluation phase, in which different options must be evaluated in order to determine and classify the alternatives. Therefore, some multi-criteria evaluation methods have been developed as "decision support systems": they do not automatically offer a choice, but rather provide help to decision-makers who face complex situations and problems characterized by a certain degree of uncertainty and information of different nature.

In order to evaluate the overall effectiveness of the alternative candidates and select the best option, the multi-criteria method requires four phases-(i) defining a set of attributes that most influence the choice of the alternative, (ii) a decision matrix, (iii) weighting of the criteria using an appropriate method, and (iv) evaluate alternatives by classifying them from best to worst.

It is possible to find several examples of the application of the Multi-Criteria Decision Aid (MCDA) methods [8] for the conservation and reuse of cultural heritage [10-15]. From an analysis of the main scientific literature with applications for MCDA in decision problems regarding cultural heritage, emerges the importance of the use of combined methodologies [16-21], which are particularly useful for dealing with complex situations [22-24], and are capable of structuring more inclusive decision-making processes aimed at a greater sharing of choices [25-27]. 
Many applications of MCDA are in the domain of cultural heritage. From the point of view of field application, the analysis shows that there are works in different research domains and that few works exist for the evaluation of cultural assets with reference to the strategies for their reuse [28]. As regards applications in the literature, multi-criteria analysis provides a theoretical and operational framework useful for supporting the design and implementation of public policy strategies in complex contexts with different values at stake and often conflicting [11-13]. The robustness of the multi-criteria methodologies is due to a series of main factors-heterogeneous criteria capable of managing both quantitative and qualitative information, multiple actors can be easily involved, the final aggregation of the different positions on adaptive reuse strategies [9-13], and the research for a solution of greater compromise that reflects the preferences of most points of view but also that of minority points [29].

This document addresses the issue of adaptive reuse of cultural heritage in a context of multi-criteria decision making and contributes to the cited literature. In detail, a decision aid system is developed, that identifies context-aware enhancement scenarios, oriented to the construction of new tangible and intangible values for the cultural heritage abandoned located in Southern Italy. What is proposed is an integrated evaluation model, based on the use of different multi-criteria methodologies, to define a classification between different scenarios and development strategies for unused historical heritage located in vulnerable contexts. The methodology is able to support the choice of an alternative reuse and to define a "shared strategy" based on a "bottom-up" approach.

The application to the case study concerns the potential reuse of six different historical fortifications (built at the end of the 18th century) located along the coasts of the Strait of Messina in Southern Italy, which are characterized by particular architectural and technical characteristics and by enormous spaces suitable for being redeveloped for new uses.

This requires the definition of the needs that must be met by the new functions assigned to the historical asset and the identification of the structural and cultural constraints to its transformation. From this perspective, a key problem is that of prior identification of the most suitable assessment methods for the decision problem.

The choice of methodology used here derives from the complementary relationship activated between the techniques of the Systems Thinking Approach [30-33] and the multi-criteria and multi-group evaluation methods, which allows us to outline a decision-making process that makes use of the specifics of each one in order to improve the knowledge of the context, to make explicit the preferences of the different stakeholders, to build shared visions of the future, and identify the preferable scenarios considering both the "qualitative" data and the "quantitative" data. The application of combined evaluation methodologies is justified by an increasingly widespread practice [30-37] aimed at overcoming the limits of each single method, to consider a multi-dimensional and plural perspective, to activate inclusive decision-making processes, and to improve the quality of the process oriented to the construction of shared choices.

The evaluation process implemented also integrates the contribution of different knowledge. It is based on the sharing of responsibilities between the different stakeholders and the concertation of choices through the complementarity between experiences and competences of different domains.

The main objective is to provide a decision support tool to design and implementation of adaptive reuse strategies of abandoned military heritage in a vulnerable context [37-39].

Furthermore, the combined use of multi-criteria techniques helps to classify unused adaptive cultural heritage reuse strategies and is able to support decision makers in implementing development strategies in vulnerable contexts. The application to the case study focuses on the potential reuse of some historical fortifications located along the coasts of the Strait of Messina. The results obtained show that the proposed model can be a useful decision support tool in contexts characterized by high complexity and that it is able to guarantee the transparency of the decision-making process for the construction of shared development strategies, in which it is necessary to highlight the elements that influence the dynamics of choice toward the best reuse project that reaches an optimal balance between conservation and usability [40-42]. 
In detail, the document is organized into five sections. Section 2 describes the methodological framework and the theoretical references of the techniques used. Section 3 presents the application to the case. Section 4 discusses the results obtained, while Section 5 traces the conclusions and identifies the research prospects.

\section{Materials and Methods}

\section{Methodological Background}

In the field of decision making, Multiple Criteria Decision Aid (MCDA) has become a widespread tool capable of dealing with problems involving more than one goal. A number of theorists $[43,44]$ and empirical studies [45-47] have shown that the MCDA can manage the complexity of the entire process and through a participatory process can help avoid conflicts and make transparent decisions more effective, involving different points of view in the initial phase of the project/problem [48].

These decision support methods, in addition to the possibility of considering data of different nature (quantitative and qualitative), offer the opportunity to assign different weights to the criteria identified, manage conflicts between objectives, and deduce priorities among alternative options.

Many Multi-Criteria Decision-Making (MCDM) methods and techniques have been proposed by researchers in the past decades. Some of the most important ones are Weighted Sum Model (WSM) [49], Weighted Product Model (WPM) [50], Weighted Aggregated Sum Product Assessment (WASPAS) [51], Analytical Hierarchy Process (AHP) [52], ELimination Et Choix TRaduisant la REalité (ELECTRE) [53], Technique for Order of Preference By Similarity to Ideal Solution (TOPSIS) [54], Preference Ranking Organization Method for Enrichment of Evaluations (PROMETHEE) [55], Complex Proportional Assessment (COPRAS) [56], Visekriterijumska Optimizacija i kompromisno Resenje (VIKOR) [57], Multiobjective Optimization by Ratio Analysis plus Full Multiplicative Form (MULTIMOORA) [58], Additive Ratio Assessment (ARAS) [59], Evaluation Based on Distance from Average Solution (EDAS) [60], and Combinative Distance-Based Assessment (CODAS).

The choice of a particular multi-criteria method depends on the specific problem and user needs. It can be pointed out that the number of existing methods is already large enough and is still increasing, and choosing the "right" method is not an easy task. To facilitate the selection of the appropriate method for decision making, a list of quality criteria has been developed [9] that can be used to reveal the strengths and weaknesses of MCDA methods compared to their application to specific problems. For the evaluation of the individual methods, quality criteria were used to highlight differences in the characteristics of the methods presented. The study also highlighted that selecting the best method is not possible. In managing complex situations, all methods show similar performances with respect to the aspects and scales that can be considered.

All the MCDM methods mentioned above have advantages and disadvantages-their evaluation is not the purpose of this document. In this document, a hybrid method to manage multi-criteria decision problems has been proposed. Furthermore, in multi-criteria analysis models, determining the weights of the criteria is another of the key problems of the decision-making process as the weights of the criteria can significantly influence the outcome of the decision-making process. It is therefore clear that particular attention must be paid to the factors of objectivity in attributing the weights to the criteria.

A study on the advantages and disadvantages of individual criteria weighting methods is provided by Roberts and Goodwin [61]; it is also recognized that the values of the weights of the criteria are significantly conditioned by the methods used for their determination [61-65].

In the literature, it is possible to find a classification [53] of the methods for determining the weights of the criteria, but there is no agreement on the best method for determining the weights of the criteria. In the literature, most authors suggest a classification of the models for determining the weights of the criteria distinguishing subjective and objective models. Subjective approaches mirror the decision maker's subjective opinion and intuition. With such an approach, the decision maker 
directly influences the outcome of the decision-making process, since the weights of the criteria are determined on the basis of information obtained from the decision maker or experts involved in the decision-making process. Objective approaches neglect the decision maker's opinion and are based on determining the weights of the criteria based on the information contained in a decision matrix that applies certain mathematical models.

The best-known subjective methods for weighting the values of the criteria are the Analytic Hierarchy Process (AHP) method, the Step-Wise Weight Assessment Ratio Analysis (SWARA), the Best Worst Method (BWM), and the Full Consistency Method (FUCOM). Each of these methods has a wide application in the various areas of science, technology, and in solving real life problems.

It can be pointed out that, despite being a relatively old method, the AHP method is still used in a large number of publications. This confirms the conclusions of Zavadskas et al. [66] that the AHP method is the most commonly used method for determining the weights of the criteria and/or classifying alternatives.

The Analytic Hierarchy Process (AHP) method [67] is certainly one of the most commonly applied methods based on pairwise comparisons to determine the weights of alternative criteria and/or rankings [67]. The validation of the results in the AHP model is based on the degree of consistency, the value of which is limited to 0.10 . In the AHP method, $n(n-1) / 2$ pairwise must be performed. It should also be added that a large number of comparisons complicate the application of the model, especially in cases of a greater number of criteria. According to some authors [68], it is almost impossible to perform fully coherent pairwise comparisons in the AHP method if more than nine criteria exist. This problem is usually overcome by dividing the criteria into sub-criteria, which further complicates the model.

Therefore, this document, in order to classify different reuse alternatives [69-71], combines different multi-criteria methods in the different stages of the decision-making process in order to develop a "quick" tool to improve the quality and reliability of the decision-making process itself, especially in the planning decision phase. The Figure 1 presents the methodological framework of the decision support process used in the work.

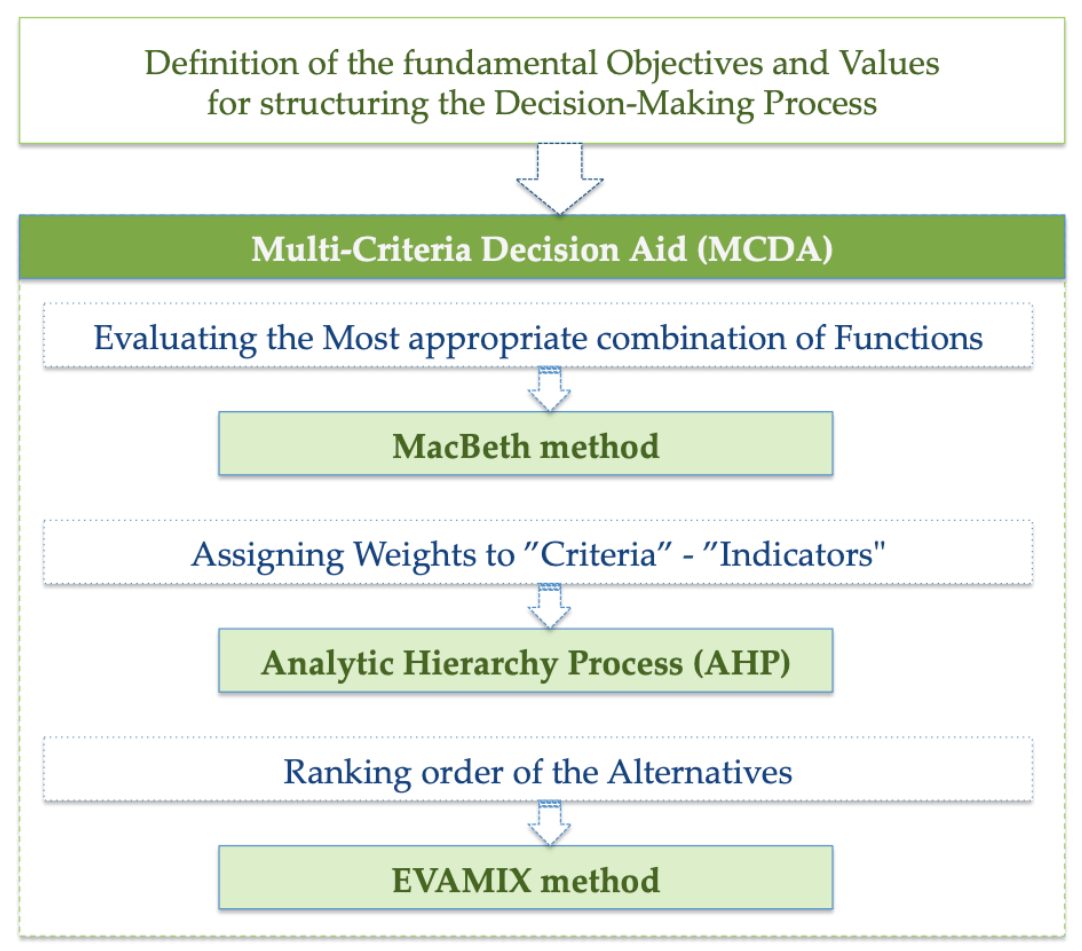

Figure 1. Methodological framework of the decision support process. 
In detail, to address the complexity of the decision problem under consideration and to support the choice about the highest and best adaptive reuse of defensive cultural heritage under study, an assessment has been implemented through the combination and integration of three multi-criteria methods: the MacBeth method [72-74], the Analytic Hierarchy Process (AHP) [68,75], and the Evaluation of Mixed data (EVAMIX) [75-79].

The combination and integration of multi-criteria methodologies [80-82] also allows the decision maker (especially in the planning phase) to classify the alternatives from the best to the worst, using a simple, effective and logical decision-making method.

In addition, the EVAMIX method was chosen as it is a fairly effective method compared to other approaches due to its simplicity of approach and the fact that it requires less time regarding the necessary mathematical calculations. To the knowledge of the authors of the article, this study represents the first experimentation relating to the combination of techniques of this type.

The application of the MacBeth evaluation method (Measuring Attractiveness by a Categorical Based Evaluation Technique) [72-74] was useful to evaluate the multidimensional impacts that the different functional choices (resulting from knowledge and participatory phases) can have on the general objective-increase the multidimensional productivity of the city. The elaboration of the data collected in the preliminary phase of knowledge and participation (focus groups and questionnaires) allowed to define the priorities regarding the functions to be included in the alternative scenarios. In the MacBeth method, the evaluation of priorities is based on pairwise comparisons and adopts an intervallic scale [8].

The Evaluation of Mixed data (EVAMIX) method [76-79], from a procedural point of view, allows the construction of an " $\mathrm{m} \times \mathrm{n}$ " evaluation matrix, characterized by " $\mathrm{m}$ " criteria and " $\mathrm{n}$ " alternative options, where the components are both qualitative rather than quantitative $[83,84]$, whose lines express the performance of each alternative with respect to a specific criterion (see APPENDIX A Matrix of Evaluation). Definite 2.0 software was used to implement the EVAMIX method [85].

From a procedural point of view, the EVAMIX method consists of seven steps, for the analytical-mathematical procedure it's possible refer to the reference literature [65-68].

In practice, the EVAMIX method consists of the following passages [76-79]:

(1) distinction between ordinal and cardinal criteria;

(2) calculation of dominance scores for all ordinal and cardinal criteria;

(3) calculation of standardized dominance scores for all ordinal and cardinal criteria;

(4) calculation of overall dominance scores;

(5) calculation of evaluation scores.

The first step is the construction of an evaluation matrix E, which is a mxn matrix, characterized by $m$ evaluation criteria and $n$ alternative options. The qualitative or quantitative data, contained in the matrix, express the performance of each alternative with respect to a given criterion.

The set of criteria is divided into two subsets- the set $\mathrm{O}$ is the set of ordinal criteria (qualitative) and the set $C$ is the set of cardinal criteria (quantitative). This leads to two distinct evaluation matrices-EO (ordinal criteria/alternative options) and CE (cardinal criteria/alternative options).

Therefore, the differences between the alternatives can be expressed through two measures of dominance, the first based on ordinal criteria, the second on cardinal criteria. In particular, in order to construct the cardinal score of dominance, the components of EC are standardized by a common unit; this allows all quantitative criteria to be expressed on a scale from 0 to 1 . The weights can be assigned to both criteria, both quantitative and qualitative.

In the second step, it is possible to calculate the "dominance scores" for all ordinal and cardinal criteria; these scores reflect the degree to which one option exceeds the other.

Subsequently (step 3), the dominance scores are standardized with the same unit of measurement to be comparable to each other, and two "standardized dominance measures" are deduced for all ordinal and cardinal criteria. 
Thus (step 4), a "measure of overall dominance" is calculated for each pair of alternatives, which translates the degree to which an option dominates over another option.

Finally (step 5), starting from the overall dominance measure, the "evaluation scores" are calculated for each alternative: the result is a complete classification of the alternatives, where the optional alternative is the one with the evaluation score higher.

The AHP Method, developed by Thomas Lorie Saaty [68,75], structures decision making in the form of hierarchy. From a procedural point of view, this method consists of the following three phases:

(1) construction of an adequate hierarchy;

(2) definition of priorities between elements of the hierarchy by comparisons in pairs;

(3) verification of the logical coherence of pairwise comparisons.

In the first step, the AHP method helps to break down complex systems into simple structures. This simplification is made possible by a logical process that aims at the construction of adequate hierarchies.

The simplest hierarchy model consists of three levels. The first level is that of the main objective (called "Objective") of the decision problem; the second and third levels include criteria and alternatives. However, it is possible to develop more complex (i.e., multi-level) hierarchies including a number of sub-criteria. This means that the factors that influence the decision are organized in gradual steps from the general, in the upper level of the hierarchy, to the particular, in the lower levels.

In the AHP method, pairwise comparisons (i.e., comparison of elements in pairs with respect to a given criterion) are used to establish priorities (or weights) between elements of the same hierarchical level (step 2). These elements are compared in pairs with respect to the elements corresponding to the next higher level. This comparison translates into a matrix of pairwise comparisons.

To represent the relative importance of one element with respect to another, a suitable evaluation scale called the "Saaty scale" is introduced. It defines and explains the values 1 to 9 assigned to the judgments to compare pairs of elements of each level with respect to a criterion in the next higher level.

Pairwise comparisons are organized in appropriate matrices, since each of them is related to "priority vectors" (expressed on a 0-1 scale) and, when aggregated, they provide a complete classification of alternatives.

For pairwise comparisons, both quantitative and qualitative data can be used. As for the third phase, it should be noted that when comparing the elements, a certain degree of inconsistency can arise: in the AHP approach, a "coherence ratio" is calculated for each matrix of pairwise comparisons to verify the degree of inconsistency. A consistency ratio of 0.10 or less is considered acceptable; if this ratio is greater than 0.10 , it is necessary to reformulate the judgments using new pairwise comparisons.

\section{Application}

\subsection{The Case Study and Presentation of the Alternatives}

This research relates to the reuse of defensive historical and cultural heritage located in Southern Italy. In particular, the study concerns the "Forti Umbertini" System located along the shores of the "Stretto di Messina" (Figure 2) of which it is possible to see some representative images in Figure 3. 


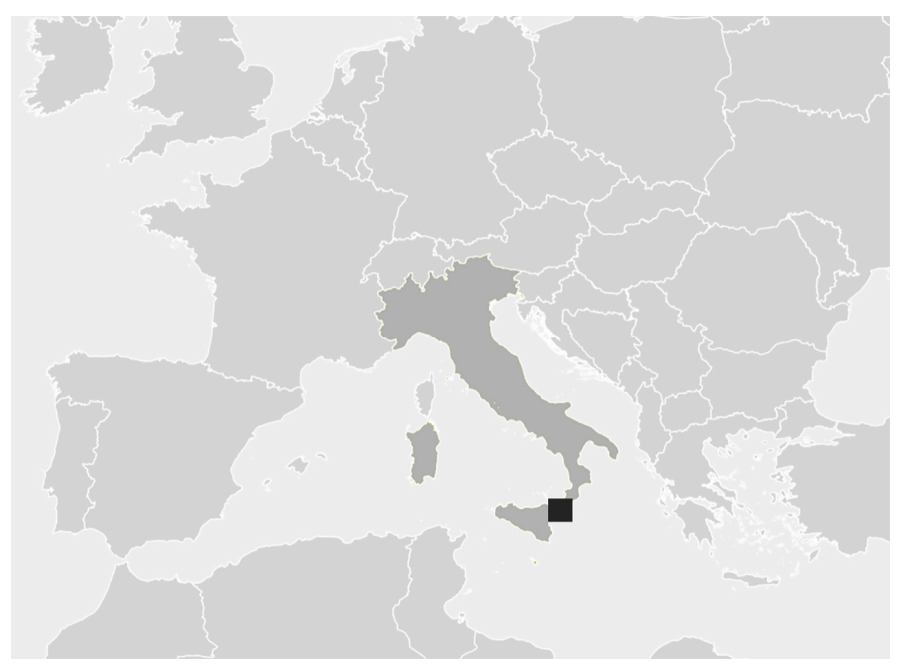

Figure 2. Location of the "Stretto di Messina" in South Italy.
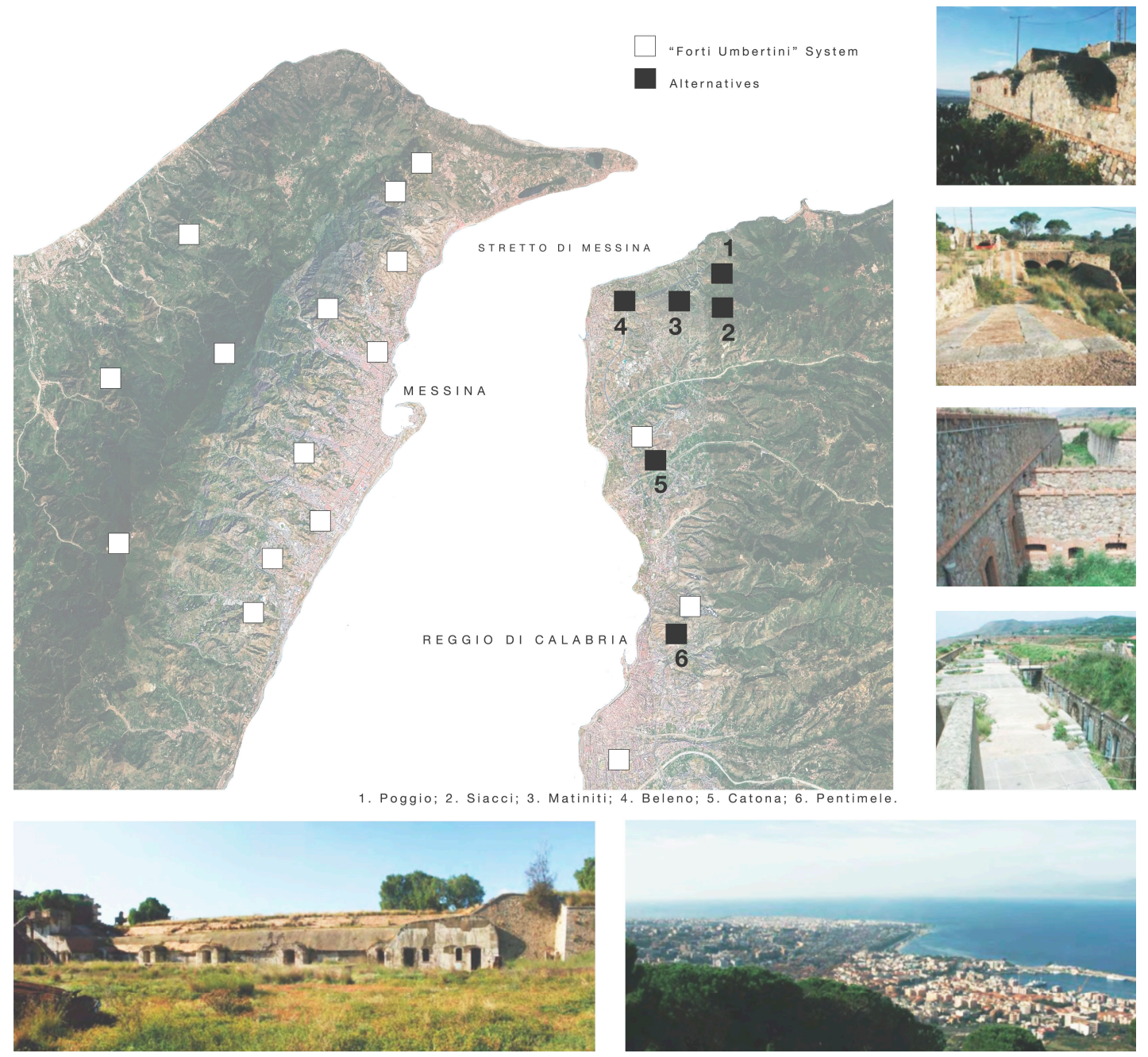

Figure 3. The "Forti Umbertini" System (source: authors' processing).

The system of the forts was built after the Italian Unification in 1860, as part of a system of military fortifications that controlled the entire eastern hill line of the Strait. It includes twenty-two fortified historic buildings, now entered into the common imagination with the term "Forti Umbertini." They were sentinels defending the waterway with the aim of not interrupting the continuity of defense 
of the new national territory. Built by the new unified Italian State in order to defend the Strait of Messina from external enemies. They form a unique system in the world consisting of twenty fortified positions placed on the two shores of Sicily and Calabria. Since the king of the time was Umberto I, they are also known as "Forti Umbertini." These camouflaged architectures ensured the defense of the territory until World War Two.

The fortified structures, which survived the 1908 earthquake and the two World Wars unscathed, since the military administration handed over deliveries to the State Property Agency, have been, for military servitude, kept away for many years from the attention of citizens and have suffered the scarce attention of local administrations that have never grasped their great tourist and economic potential.

Starting from the analysis of the network of Forts located in the area [86] we have identified six alternative buildings not yet used and enhanced, thus allowing the introduction of new functions and destinations. The Figure 3 shows the map with the alternatives considered in the evaluation process.

\subsection{Implementation of Multicriteria Methods to the Case Study}

The main objective of the research is to identify among the six forts what is most suitable for hosting new functions/uses.

In order to assess the suitability of the cultural heritage selected for adaptive reuse, through a participatory process four potential reuse scenarios have been identified, which represent four different alternative uses.

In the present study, the evaluation was conducted through the integration of three multi-criteria approaches-the MacBeth method, AHP, and EVAMIX [76-79]. The MacBeth method [60-62] was helpful when evaluating the most appropriate combination of functions to enhance the historical heritage and resources of the territory, the EVAMIX method [6] was used to deduce a classification among the alternatives, characterized by qualitative and quantitative information. The AHP method $[68,75]$ was used to assign weights to "criteria" and "indicators."

\subsubsection{MacBeth Implementation of the Method}

The preliminary assessment phase was useful for processing the data collected, through focus groups and questionnaires, and defining the alternatives/functions to be included in the cultural heritage under study.

The participatory process has allowed users to acquire local information, analyze possible conflicting behaviors, and produce more preferable and shared alternatives. In this phase, four groups of stakeholders have been identified:

- Institutions: Calabria Region, Metropolitan city, Municipality, Superintendence;

- Technical-professional organizations: Professional Association of Geologists, Professional Association of Architects, Professional Association of Engineers;

- Professionals in real estate and cultural heritage;

- Association of Builders Construction of Reggio Calabria (ACEN), Industrial Union, Trade Union;

- Tourism and Trading;

- Community: Residents, Representatives of associations.

The questionnaires were administered to the community and to the association's representatives; focus groups involved representatives of institutions and technical-professional organizations.

Below is the list of functions deduced from the participatory process.

1. Co-working spaces;

2. Spaces for higher education;

3. Multimedia library;

4. Spaces for theater activities;

5. Music school; 
6. Artistic workshops;

7. Concert hall;

8. Production and tasting of food and wine products;

9. Sale of local food products;

10. Residence, wellness centers, beauty farm, and meeting room;

11. Sport, Health, and Wellness;

12. Museum spaces.

For the evaluation of the priorities of the alternative functions to be used for the implementation of the scenarios, the MacBeth evaluation method [72-74] wich was chosen for the possibility of processing qualitative judgments from various data sources (focus groups and questionnaires). This method uses a synthetic matrix, which links options (functions) to potential multi-dimensional impacts on defined impact categories/criteria.

The impact indicators have been extracted, through focus groups with expert actors, and take into account the multidimensional impacts (economic, social, environmental, and cultural) on the wider territorial area according to the systemic perspective of the landscape proposed in the UNESCO recommendation on the historical urban landscape $[87,88]$. The categories of impact/criteria are i. Tourism and recreation; ii. Creative, cultural and innovative activities; iii. Local typical productions; iv. Environment and natural capital; v. Social and community cohesion, vi. Real estate; vii. Financial performance; viii. Welfare; ix. Cultural value of the property/landscape, which have been identified in relation to the general objective aimed at increasing productivity in more dimensions of the territory interested [89].

A judgment matrix was then elaborated with pairwise comparisons between the different alternative functions with respect to each indicator. Impacts of each function on each category of indicators were determined starting from the qualitative judgments expressed using the seven semantic categories of MacBeth (no impact; very weak; weak; moderate; strong; very strong; extreme).

After the phase referring to each fundamental criterion and to the attribution of the weights, the final aggregation phase was elaborated and a final classification of preferences was elaborated in relation to the general objective. Below, the MacBeth scale represents the final classification of the impacts that each option/function has on the criteria.

11. Sport, Health and Wellness;

6. Artistic workshops;

5. Music school;

4. Spaces for the theater;

7. Concert hall;

10. Residence, wellness centers, beauty farm, and meeting room;

2. Spaces for higher education;

9. Sale of local food products;

8. Production and tasting of food and wine products;

1. Co-working spaces;

3. Multimedia library;

12. Museum spaces.

The group of experts (entrepreneurs, investors, and professionals in the real estate, tourism, and cultural heritage sectors) subsequently interacted and combined the various selected functions (among those that were compatible) and designed four adaptive reuse scenarios, representative of potential changes in current use on the economic, social, environmental and cultural plan. 


\subsubsection{EVAMIX Implementation of the Method}

In relation to the chosen functions and in order to assess the suitability for adaptive reuse of the six selected forts, four potential reuse scenarios have been implemented. These scenarios represent the potential uses that can be successfully hosted in the military fortifications in question. The scenarios are the result of the combination of the functions selected through the MacBeth Method [72,73,73].

In relation to each decision scenario, the six alternative buildings have been evaluated and classified from the most to the least suitable for use in relation to each scenario, based on the criteria chosen based on the characteristics of the alternatives to be evaluated.

To structure the EVAMIX decision process [76-79] we proceeded according to the following phases:

Step 1. Identification of the assessment scenarios. Four different scenarios have been designed by the group of experts, as a result from of the integration of multiple functions chosen among those classified and judged most suitable and representative of potential changes in term of economic, social, environmental and cultural terms development. The following scenarios represent real and potential uses that can be successfully hosted in abandoned fortifications:

- Artistic/Cultural Park: art gallery, studios/residences/artists' workshops (designers, architects, painters, sculptors, etc.).

- Design Center: co-working spaces, multi-functional equipped classrooms with spaces for conferences and university events and high education, museums, bars, and restaurants.

- Food Farm: theme park dedicated to agribusiness. Meeting areas for schools, universities and companies. The idea is to offer study courses on the production techniques of local products and wine and food itineraries of the Strait Region.

- Health and Wellness Center: heliotherapy, thalassotherapy, kiosks and bars, green public areas, recreational paths for childcare, urban agriculture

Step 2. Construction of the criteria tree. The set of criteria used in the evaluation process was formulated by a focus group of experts including entrepreneurs, investors and professionals in the real estate, tourism and cultural heritage sectors, in which the different points of view were discussed. Subsequently the research group has elaborated and translated the information in a limited number of criteria [68], clearly defined based on the characteristics of the alternatives to be evaluated, choosing above all the relevant ones (coherence with the objectives of the project) because a large number of indicators could make the evaluation process more complex and less effective.

The structure of the criteria considers the relevant aspects of the decision-making problem under consideration - environmental quality, economic aspects, context infrastructuring, and architectural features-in relation to the main strategic objective of the decision maker (DM) to create a new catalyst for the entire urban development process of the Strait area.

Step 3. Construction of the evaluation matrix. A $11 \times 6$ matrix characterized by mxn (eleven evaluation criteria $x$ six alternative options) whose components are cardinal (quantitative) and ordinal (qualitative) data, which express the impact/performance of each alternative with respect to a given criterion. The evaluation matrix is shown in Appendix A.

Step 4. Criteria weighting. To assess the importance of the criteria, we made some interviews with the group of experts to indicate the weights for each of the criteria. Then AHP method was therefore implemented of the comparison in pairs [68,75], through the use of the "Saaty scale," to establish priorities (weights) and compare pairs of elements of each level with respect to a criterion in the next higher level. During the brainstorming process, with the help of a moderator, the experts reached consensus on the final set of weights.

The overall set of weights of criteria and sub-criteria is displayed in Appendix A. Note that, in the evaluation matrix, the values enclosed in round brackets are weights assigned in the AHP assessment [68,75].

Step 5. Classification of alternatives. In order to obtain the priority vectors and the final ranking, the EVAMIX method was implemented in the Definite 2.0 software [85]. 
In order to classify the adaptive reuse alternatives with respect to each scenario, it was simulated the investment decision of potential Decision Makers (DM) who expressed their expert judgment [90]. To this end, on the basis of their relevant experience and strong interest in the reuse of historical-cultural buildings, the group of experts was asked to identify which of the four adaptive reuse scenarios is the most suitable for the six alternatives of historic fortifications under study.

The results and the ranking order of alternatives are discussed in the following section.

\section{Results and Discussion}

Figures 4 and 5 show the overall values of the EVAMIX assessment and the ranking of alternatives for the different uses considered in the study. According to the results obtained, alternative 1. Poggio is the most suitable building to be reused for different purposes and scenarios considered: Design Center, Artistic/Cultural Park, Health and Wellness Center, and Food Farm.

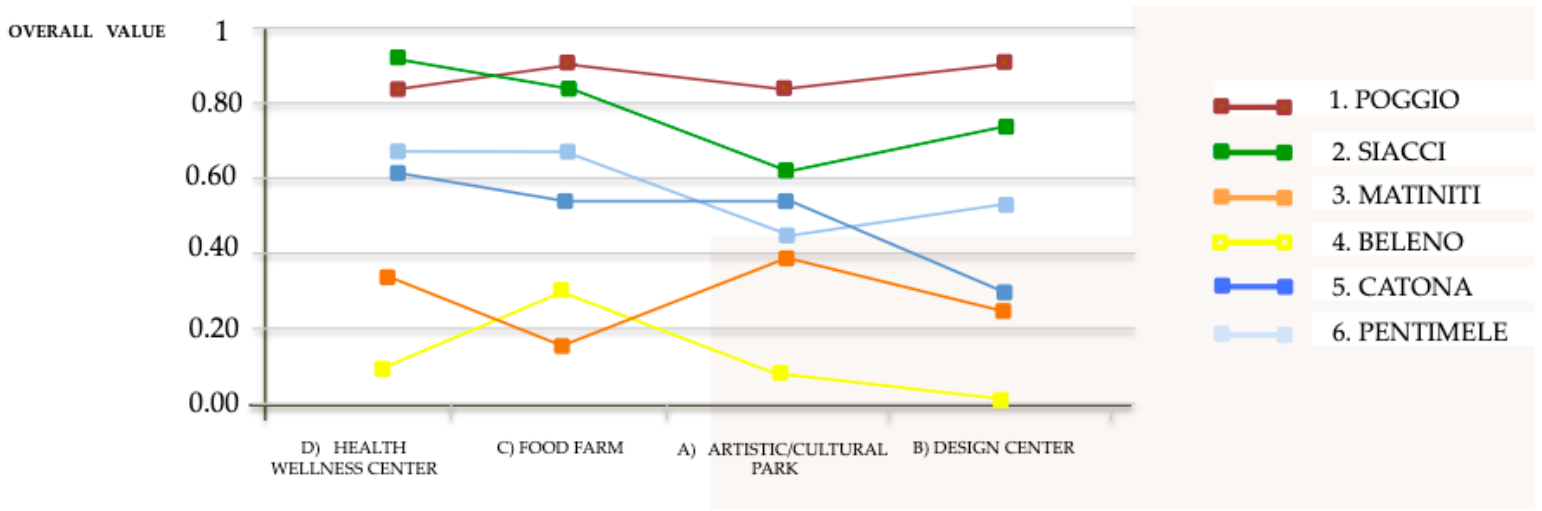

Figure 4. Evaluation of Mixed data (EVAMIX) method: overall value for the different scenarios.

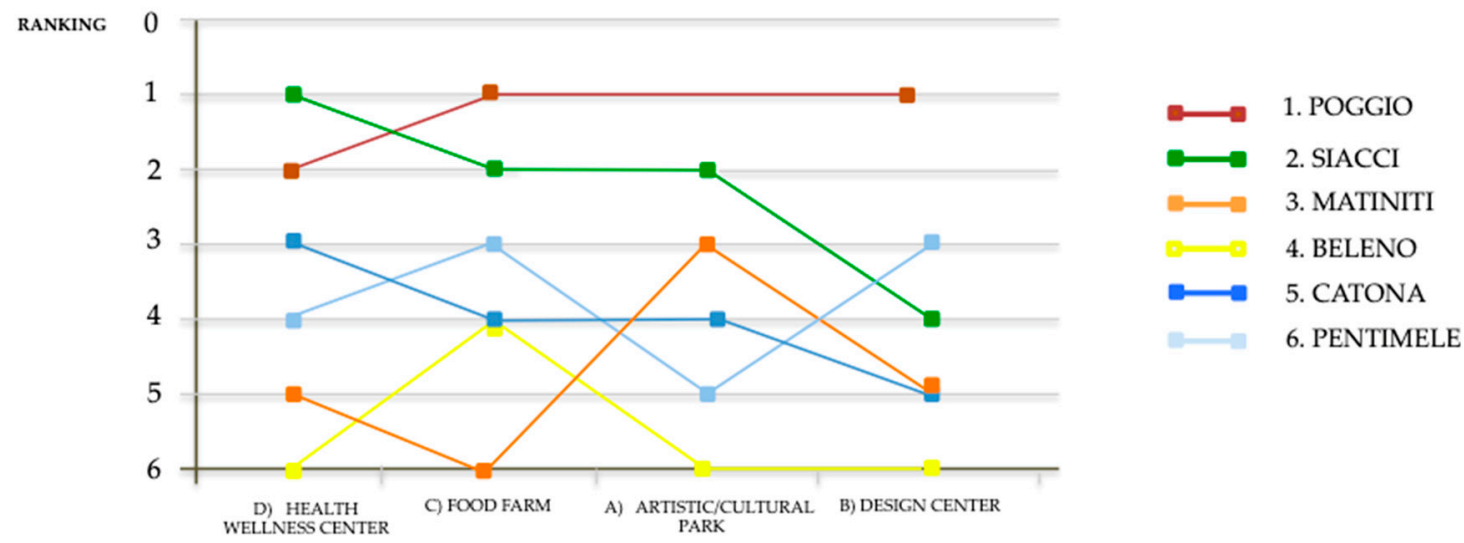

Figure 5. EVAMIX method: ranking of the alternatives for the different scenarios.

From the results obtained, it is possible to say that the "1. Poggio" alternative is the best alternative for three out of four scenarios. The alternative "2. Siacci" also has excellent performance, since it is classified as the best alternative for the scenario: Health and Wellness Center and as the second best alternative for the scenarios: Design Center, Artistic/Cultural Park, Agriturismo. Furthermore, it should be noted that the "Beleno" is the alternative classified as the worst alternative in three out of four scenarios.

This result is influenced by the greater weight (relative importance) attributed by the experts to the criterion "Project Sustainability" (relative to the indicators: Degradation level, architectural characteristics and Flexibility of spaces to new functions, Total property availability), which in relation to the potential for reuse are of great importance [91] (Appendix A). 
After obtaining a classification of alternatives and checking the consistency obtained in the results, it is useful to carry out a sensitivity analysis on the final outcome of the model. Sensitivity analysis concerns a type of "what if" question, which allows us to check if the final answer is stable when the model inputs are changed. It is of particular interest to see if these changes change the order of the alternatives.

In the present study, sensitivity analysis was performed regarding the weights of the criteria. In particular, the weight of one criterion at a time was increased up to $60 \%$ while the weights of the other criteria were kept equal to $20 \%$. The evaluation model was performed considering again the weights and the final priorities of the alternatives were recalculated.

The Figure 6 represents the results of the sensitivity analysis performed. As can see, three alternatives-Poggio, Siacci, and Pentimele-have the best performances among the scenarios considered, while the Beleno alternative is ranked last.

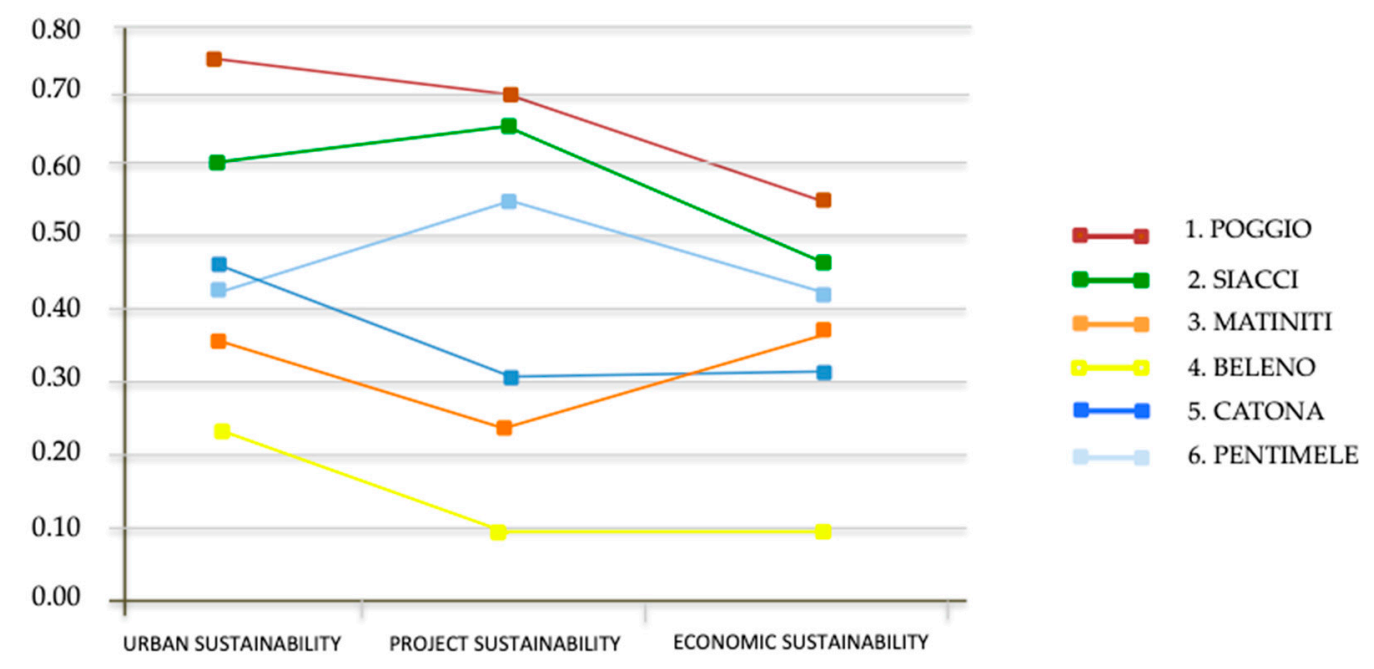

Figure 6. EVAMIX method: results of the sensitivity analysis.

\section{Conclusions}

This document proposes a methodology that integrates different multi-criteria evaluation methods to support the decision-making process regarding the choice of sustainable alternative functions, aimed at the adaptive reuse of the historical-cultural heritage [92]. This theme is of particular importance because the phenomenon of the reuse of unused or abandoned historical and cultural heritage is becoming increasingly important, especially in Italy, where there are thousands of architectural quality assets that constitute a real resource for the territory.

The multi-criteria decision support method uses qualitative and quantitative criteria to evaluate four different reuse scenarios for the redesign of the "Forti Umbertini" system located in Southern Italy. The different scenarios were designed by a group of experts who also assigned the weights to the different criteria involved in the evaluation model.

The nature of the public goods considered by the enhancement projects and the strong articulation that characterizes the territorial redevelopment projects require complex approaches.

The application developed in the present study proved to be very advantageous, especially when planning interventions, to support complex decisions, about alternative scenarios, in which it is necessary to make a choice regarding alternative scenarios that take into account different points of view and the involvement of experts in the evaluation process.

For this purpose, the evaluation process was structured in order to incorporate the participation of all stakeholders in defining a "shared solution" capable of meeting the needs of the local community, and at the same time being sustainable over time from an economic point of view. 
The methodological approach based on the integration of participatory processes and the multi-criteria analyzes, in a proposed multidimensional perspective, allowed to include the opinions of the stakeholders in the decision-making process. In this study, the involvement of the local community is one of the key factors for the success of this type of process and represented a fundamental support for the decision-making process. The integration between the community and specialist knowledge guarantees a higher level of acceptability of the results, reaching greater consensus, outlining strategies that are as shared as possible. It helps guide strategic choices better. The involvement of all stakeholders and actors facilitated the acquisition of information and knowledge that supported the decision-making process; it also ensured credibility and transparency in the process. In addition, this integrated evaluation process, in addition to considering the point of view of the various stakeholders, has enabled the generation of alternatives (possible functions) to be considered. Through the participation of all interested parties, the implementation and integration of multi-criteria methodologies, it was possible to define a "shared solution" and obtain a ranking of the alternatives for each decision scenario.

According to the results obtained, the "Poggio" alternative is the most suitable building to be reused for different purposes. This is due to the fact that the building is in good condition and the space configuration is very flexible to accommodate new and differentiated functions. The "Siacci" alternative contains the best features to be reused as a Health and Wellness Center due to the possibility of a large area that can be used for complementary functions. On the contrary, the "Beleno" alternative is classified in the last position in all the decision scenarios considered.

The results obtained, validated by the sensitivity analysis, are consistent in defining the most suitable building for adaptive reuse with respect to specific uses.

This study could have interesting implications, as it could represent a useful tool for policy makers in the process of planning and designing a general plan aimed at re-launching and enhancing the immense heritage with a view to creating a circular economy and promoting the economic development of the territory under investigation [93].

Today, the new challenge for local authorities is to regenerate abandoned heritage buildings while involving various stakeholders and the local community in order to create new governance models that are able to guarantee economic sustainability and conservation of values of historical and cultural heritage [94-96], as in the case of the "Forti Umbertini" under study, which have always been a symbol for the Strait community.

According to this perspective, future research in this field can be oriented towards the search for new management models, based on the concept of "heritage as common goods" [97-99], based on agreements between public promoters and Profit or No-Profit associations for the management of common goods $[95,96]$.

Funding: This research received no external funding.

Conflicts of Interest: The author declare no conflict of interest. 


\section{Appendix A. Evaluation Matrix}

\begin{tabular}{|c|c|c|c|c|c|c|c|c|c|}
\hline \multirow{2}{*}{ CRITERIA } & \multirow{2}{*}{ INDICATORS } & \multirow{2}{*}{ Goal } & \multirow{2}{*}{ Unit } & \multicolumn{6}{|c|}{ Alternatives } \\
\hline & & & & 1 Poggio & 2 Siacci & 3 Matiniti & 4 Beleno & 5 Catona & 6 Pentimele \\
\hline \multirow[t]{5}{*}{$\begin{array}{l}\text { URBAN } \\
\text { SUSTAINABILITY }(0.30)\end{array}$} & $\begin{array}{l}\text { Presence of historical-cultural places within } 1 \\
\mathrm{~km}(0.25)\end{array}$ & $\max$ & $1-5$ & 4 & 4 & 3 & 2 & 5 & 5 \\
\hline & Quality of the urban landscape (0.30) & rank & $1-5$ & 5 & 4 & 5 & 3 & 3 & 5 \\
\hline & Accessibility by private car $(0.15)$ & $\min$ & $\mathrm{km}$ & 7 & 8 & 7 & 10 & 2,5 & 1 \\
\hline & Presence of commercial activities nearby $(0.10)$ & $\max$ & $1-5$ & 3 & 2 & 2 & 2 & 2 & 3 \\
\hline & $\begin{array}{l}\text { Presence of accommodation and hospitality } \\
\text { services }(0.20)\end{array}$ & $\max$ & $1-5$ & 3 & 3 & 4 & 1 & 1 & 3 \\
\hline \multirow[t]{3}{*}{$\begin{array}{l}\text { PROJECT } \\
\text { SUSTAINABILITY }(0.40)\end{array}$} & Total property availability $(0.25)$ & $\max$ & sqm & 19,600 & 18,300 & 8200 & 10,800 & 7300 & 6600 \\
\hline & Flexibility of spaces to new functions $(0.40)$ & rank & $1-5$ & 3 & 2 & 3 & 2 & 4 & 4 \\
\hline & Degradation level (0.40) & rank & $1-5$ & 3 & 3 & 3 & 2 & 3 & 3 \\
\hline \multirow[t]{3}{*}{$\begin{array}{l}\text { ECONOMIC } \\
\text { SUSTAINABILITY }(0.30)\end{array}$} & Investment costs $(0.25)$ & $\min$ & $€ /$ sqm & 1200 & 1320 & 1550 & 1250 & 1400 & 1700 \\
\hline & Payback period (0.25) & $\min$ & year & 3 & 4 & 6 & 5 & 4 & 6 \\
\hline & Financial appeal for private investors $(0.50)$ & $\max$ & $1-5$ & 3 & 4 & 4 & 3 & 5 & 5 \\
\hline
\end{tabular}




\section{References}

1. Klamer, A. The values of cultural heritage. In Handbook on the Economics of Cultural Heritage; Rizzo, I., Mignosa, A., Eds.; Edward Elgar: Cheltenham, UK, 2013.

2. Fusco Girard, L.; Gravagnuolo, A. Circular economy and cultural heritage/landscape regeneration. Circular business, financing and governance models for a competitive Europe. BDC 2017, 2017, 35-52.

3. Zeleny, M. Autopoiesis and self-sustainability in economic systems. Hum. Syst. Manag. 1997, 16, $251-262$. [CrossRef]

4. Kincaid, D. Adapting Buildings for Changing Uses: Guidelines for Change of Use Refurbishment; Spon: New York, NY, USA, 2002.

5. Wang, H.; Zeng, Z. A multi-objective decision-making process for reuse selection of historic buildings. Expert Syst. Appl. 2010, 37, 1241-1249. [CrossRef]

6. Fuentes, J.M. Methodological bases for documenting and reusing vernacular farm architecture. J. Cult. Herit. 2010, 11, 119-129. [CrossRef]

7. Simons, R.A.; Choi, E. Adaptive Reuse of Religious Buildings and Schools in the US: Determinants of Project Outcomes. Int. Real Estate Rev. 2010, 13, 79-108.

8. Ishizaka, A.; Nemery, P. Multi-Criteria Decision Analysis: Methods and Software; Wiley: Chichester, UK, 2013.

9. De Montis, A.; De Toro, P.; Droste-Franke, B.; Omann, I.; Stagl, S. Assessing the quality of different MCDA methods. In Alternatives for Environmental Evaluation; Getzner, M., Spash, C.L., Stagl, S., Eds.; Routledge: Abingdon-on-Thames, UK, 2004; pp. 99-133.

10. Ferretti, V.; Bottero, M.; Mondini, G. Decision making and cultural heritage: An application of the Multi-Attribute Value Theory for the reuse of historical buildings. J. Cult. Herit. 2014, 15, 644-655. [CrossRef]

11. Plevoets, B.; Van Cleempoel, K. Adaptive reuse as a strategy towards conservation of cultural heritage: A literature review. WIT Trans. Built Environ. 2011, 118, 155-164.

12. Elsorady, D. The economic value of heritage properties in Alexandria, Egypt. J. Cult. Herit. 2014, 15, 511-521. [CrossRef]

13. Giove, S.; Rosato, P.; Breil, M. An application of Multicriteria Decision Making to built heritage. The redevelopment of Venice Arsenale. J. Multi. Crit. Decis. Anal. 2011, 17, 85-99. [CrossRef]

14. Misırlısoy, D.; Gunçe, K. Adaptive reuse strategies for heritage buildings: A holistic approach. Sustain. Cities Soc. 2016, 26, 91-98. [CrossRef]

15. Bryan, B.A.; Grandgirard, A.; Ward, J.R. Quantifying and exploring strategic regional priorities for managing natural capital and ecosystem services given multiple stakeholder perspectives. Ecosystems 2010, 13, 539-555. [CrossRef]

16. Thórhallsdóttir, T.E. Environment and energy in Iceland: A comparative analysis of values and impacts. Environ. Impact Asses 2007, 27, 522-544. [CrossRef]

17. Hamadouche, M.A.; Mederbal, K.; Kouri, L.; Regagba, Z.; Fekir, Y.; Anteur, D. GIS-based multicriteria analysis: An approach to select priority areas for preservation in the Ahaggar National Park, Algeria. Arab J. Geosci. 2014, 1-16. [CrossRef]

18. Palmas, C.; Abis, E.; von Haaren, C.; Lovett, A. Renewables in residential development: An integrated GIS-based multicriteria approach for decentralized micro-renewable energy production in new settlement development: A case study of the eastern metropolitan area of Cagliari, Sardinia, Italy. Energy Sustain. Soc. 2012, 2, 1-15. [CrossRef]

19. Di Bitonto, P.; Laterza, M.; Roselli, T.; Rossano, V. Multicriteria retrieval in cultural heritage recommendation systems. In KES 2010, Part II, LNAI 6277; Setchi, R., Setchi, R., Jordanov, I., Howlett, R.J., Jain, L.C., Eds.; Springer: Berlin, Germany, 2010; pp. 64-73.

20. Paolillo, P.L.; Benedetti, A.; Baresi, U.; Terlizzi, L.; Graj, G. An assessment-based process for modifying the built fabric of historic centres: The case of Como in Lombardy. In Computational Science and Its Applications - ICCSA 2011 (vol 6782); Murgante, B., Gervasi, O., Iglesias, A., Taniar, D., Apduhan, B.O., Eds.; Springer: Berlin, Germany, 2011; pp. 162-176.

21. Tarragüel, A.A.; Krol, B.; van Westen, C. Analysing the possible impact of landslides and avalanches on cultural heritage in Upper Svaneti, Georgia. J. Cult. Herit. 2012, 13, 453-461. [CrossRef] 
22. Cerreta, M.; Panaro, S.; Cannatella, D. Multidimensional spatial decision-making process: Local shared values in action. In ICCSA 2012, Part II, LNCS 7334; Murgante, B., Gervasi, O., Misra, S., Nedjah, N., Rocha, A.M.A.C., Taniar, D., Apduhan, B.O., Eds.; Springer: Berlin, Germany, 2012; pp. 54-70.

23. Girard, L.F.; De Toro, P. Integrated spatial assessment: A multicriteria approach to sustainable development of cultural and environmental heritage in San Marco dei Cavoti, Italy. CEJOR 2007, 15, 281-299. [CrossRef]

24. Fuentes, J.M. Basi metodologiche per documentare e riutilizzare l'architettura della fattoria vernacolare; Elsevier: Amsterdam, The Netherlands, 2010; pp. 119-129.

25. Dutta, M.; Husain, Z. An application of Multicriteria Decision Making to built heritage. The case of Calcutta. J. Cult. Herit. 2009, 10, 237-243. [CrossRef]

26. Geraedts, R.P.; van der Voordt, T.; Remøy, H. Conversion Potential Assessment Tools. In Building Resilience in Urban Settlements through Sustainable Change of Use; Remøy, H., Wilkinson, S.J., Eds.; Wiley-Blackwell: Hoboken, NJ, USA, 2018; pp. 121-151. ISBN 978-1-119-23142-4.

27. Celadyn, M. Interior Architectural Design for Adaptive Reuse in Application of Environmental Sustainability Principles. Sustainability 2019, 11, 3820. [CrossRef]

28. Pinto, M.R.; De Medici, S.; Senia, C.; Fabbricatti, K.; De Toro, P. Building reuse: Multi-criteria assessment for compatible design. Int. J. Des. Sci. Technol. IJDST 2017, 22, 165-193.

29. Roy, B. Multicriteria methodology for decision aiding; Springer Science \& Business Media: Berlin, Germany, 2013; Volume 12.

30. Bánáthy, B.H. Guided Evolution of Society: A Systems View (Contemporary Systems Thinking); Springer: Berlin, Germany, 2000.

31. Jackson, M. Systems Thinking: Creating Holisms for Managers; Wiley: Chichester, UK, 2003.

32. Checkland, P.; Poulter, J. Learning for Action; Wiley: Chichester, UK, 2006.

33. Ackoff, R.L. Systems Thinking for Curious Managers; Triarchy Press: Gillingham, UK, 2010.

34. Allmendinger, P.; Haughton, G. Soft spaces, fuzzy boundaries, and metagovernance: The new spatial $\mathrm{p}$ lanning in the Thames Gateway. Environ. Plan. A 2009, 41, 617-633. [CrossRef]

35. Carlsson-Kanyama, A.K.; Dreborg, H.; Moll, H.; Padovan, D. Participative backcasting: A tool for involving stakeholders in local sustainability planning. Futures 2007, 40, 34-46. [CrossRef]

36. Fusco Girard, L.; Cerreta, M.; De Toro, P. Integrated planning and integrated evaluation. Theoretical references and methodological approaches. In Beyond Benefit Cost Analysis. ACCOUNTING for Non-Market Values in Planning Evaluation; Miller, D., Patassini, D., Eds.; Ashgate: Aldershot, UK, 2005; pp. 175-205.

37. Pearce, D.W.; Turner, R.K. Economics of Natural Resources and the Environment; Johns Hopkins University Press: Baltimore, MD, USA, 1990.

38. European Commission. Towards an Integrated Approach to Cultural Heritage for Europe. 2014. Available online: http://ec.europa.eu/culture/library/publications/2014-heritage-communication_en.pdf (accessed on 22 July 2014).

39. Della Spina, L.; Giorno, C.; Galati Casmiro, R. Bottom-Up Processes for Culture-Led Urban Regeneration Scenarios. In Computational Science and Its Applications - ICCSA 2019, (Lecture Notes in Computer Science Book, Volume 11622); Misra, S., Gervasi, O., Murgante, B., Stankova, E., Korkhov, V., Torre, C., Rocha, A.M.A.C., Taniar, D., Apduhan, B.O., Tarantino, E., Eds.; Springer: Cham, Switzerland, 2019; pp. 93-107. [CrossRef]

40. Throsby, D. Investment in urban heritage conservation in developing countries: Concepts, methods and data. City Cult. Soc. 2016, 7, 81-86. [CrossRef]

41. Della Spina, L. Evaluation Decision Support Models: Highest and Best Use Choice. Procedia Soc. Behav. Sci. 2016, 223, 936-943. [CrossRef]

42. Della Spina, L.; Calabrò, F. Decision Support Model for Conservation, Reuse and Valorization of the Historic Cultural Heritage. In Computational Science and Its Applications - ICCSA 2018. Lecture Notes in Computer Science Book Series; Gervasi, O., Murgante, B., Misra, S., Stankova, E., Torre, C.M., Rocha, A.M.A.C., Taniar, D., Apduhan, B.O., Tarantino, E., Ryu, Y., Eds.; Springer: Cham, Switzerland, 2018; volume 10962, pp. 3-17. [CrossRef]

43. Munda, G. Multiple Criteria Evaluation in a Fuzzy Environment - Theory and Applications in Ecological Economics; Springer Physika Verlag: Heidelberg, Germany, 1995.

44. Castells, N.; Munda, G. International environmental issues: Towards a new integrated assessment approach. In Valuation and the Environment - Theory, Method and Practice; O'Connor, M., Spash, C., Eds.; Edward Elgar: Cheltenham, UK, 1999; pp. 309-327. 
45. Janssen, R. Multiobjective Decision Support for Environmental Management; Kluwer Academic: Dortrecht, The Netherlands, 1992.

46. Andreoli, M.; Tellarini, V. Farm sustainability evaluation: Methodology and practice. Agric. Ecosyst. Environ. 2000, 77, 43-52. [CrossRef]

47. Mendoza, G.A.; Prabhu, R. Multiple criteria decision making approaches to assessing forest sustainability using criteria and indicators: A case study. For. Ecol. Manag. 2000, 131, 107-126. [CrossRef]

48. Roy, B. Decision-aid and decision-making. Eur. J. Oper. Res. 1990, 45, 324-331. [CrossRef]

49. Fishburn, P.C. Additive Utilities with Incomplete Product Sets: Application to Priorities and Assignments. Oper. Res. 1967, 15, 537-542. [CrossRef]

50. Miller, D.W.; Starr, M.K. Executive Decisions and Operations Research; Prentice-Hall: Upper Saddle River, NJ, USA, 1969.

51. Zavadskas, E.K.; Turskis, Z.; Antucheviciene, J.; Zakarevicius, A. Optimization of Weighted Aggregated Sum Product Assessment. Elektron. Elektrotech. 2012, 122, 3-6. [CrossRef]

52. Saaty, T.L. How to Make a Decision: The Analytic Hierarchy Process. Eur. J. Oper. Res. 1981, 48, 9-26. [CrossRef]

53. Roy, B. Classement et choix en présence de points de vue multiples. RAIRO Oper. Res. Rech. Opér. 1968, 2, 57-75. [CrossRef]

54. Hwang, C.L.; Yoon, K. Multiple Attribute Decision Making: Methods and Applications: A State-of-the-Art Survey; Springer-Verlag: Dortrecht, The Netherlands, 1981.

55. Brans, J.P.; Vincke, P. Note-A Preference Ranking Organisation Method. Manag. Sci. 1985, 31, $647-656$. [CrossRef]

56. Zavadskas, E.; Kaklauskas, A. Determination of an Efficient Contractor by Using the New Method of Multicriteria Assessment. International Symposium for "The Organization and Management of Construction"; Langford, D.A., Retik, A., Eds.; Shaping Theory and Practice: London, UK, 1996; pp. 94-104.

57. Opricovic, S. Multicriteria Optimization of Civil Engineering Systems; Faculty of Civil Engineering: Belgrade, Serbia, 1998.

58. Brauers, W.K.M.; Zavadskas, E.K. Project Management by Multimoora as an Instrument for Transition Economies. Technol. Econ. Dev. Econ. 2010, 16, 5-24. [CrossRef]

59. Zavadskas, E.K.; Turskis, Z. A New Additive Ratio Assessment (ARAS) Method in Multicriteria Decision-Making. Technol. Econ. Dev. Econ. 2010, 16, 159-172. [CrossRef]

60. Keshavarz Ghorabaee, M.; Zavadskas, E.K.; Olfat, L.; Turskis, Z. Multi-criteria Inventory Classification Using a New Method of Evaluation Based on Distance from Average Solution (EDAS). Informatica 2015, 26, 435-451. [CrossRef]

61. Roberts, R.; Goodwin, P. Weight approximations in multi-attribute decision models. J. Multicrit. Decis. Anal. 2002, 11, 291-303. [CrossRef]

62. Solymosi, T.; Dompi, J. Method for determining the weights of criteria: The centralized weights. Eur. J. Oper. Res. 1985, 26, 35-41. [CrossRef]

63. Cook, W.D. Distance-based and ad hoc consensus models in ordinal preference ranking. Eur. J. Oper. Res. 2006, 172, 369-385. [CrossRef]

64. Weber, M.; Borcherding, K. Behavioral influences on weight judgments in multiattribute decision making. Eur. J. Oper. Res. 1993, 67, 1-12. [CrossRef]

65. Tzeng, G.-H.; Chen, T.-Y.; Wang, J.C. A weight-assessing method with habitual domains. Eur. J. Oper. Res. 1998, 110, 342-367. [CrossRef]

66. Zavadskas, E.K.; Govindan, K.; Antucheviciene, J.; Turskis, Z. Hybrid multiple criteria decision-making methods: A review of applications for sustainability issues. Econ. Res. Ekon. Istraž. 2016, 29, 857-887. [CrossRef]

67. Saaty, T.L. The Analytic Hierarchy Process for Decision in a Complex World; RWS Publications: Pittsburgh, PA, USA, 1980.

68. Zhu, G.N.; Hu, J.; Qi, J.; Gu, C.C.; Peng, J.H. An integrated AHP and VIKOR for design concept evaluation based on rough number. Adv. Eng. Inform. 2015, 29, 408-418. [CrossRef]

69. Giacomini, C.; Longo, G.; Lunardi, A.; Padoano, E. AHP-Aided Evaluation of Logistic and Transport Solutions in a Seaport. In Applications and Theory of Analytic Hierarchy Process-Decision Making for Strategic Decisions; Tech: Bruchsal, Germany, 2016; pp. 115-141. 
70. Raymundo, H.; Reis, J.G.M. Passenger Transport Drawbacks: An Analysis of Its “Disutilities” Applying the AHP Approach in a Case Study in Tokyo, Japan. In Proceedings of the IFIP International Conference on Advances in Production Management Systems, Riga, Latvia, 17-20 October 2018; pp. 545-552.

71. Olivková, I. Methodology for Assessment of Electronic Payment Systems in Transport Using AHP Method. In Proceedings of the International Conference on Reliability and Statistics in Transportation and Communication, Riga, Latvia, 17-20 October 2018; pp. 290-299.

72. Bana, E.; Costa, C.A.; Vansnick, J.C. MACBETH-An interactive path towards the construction of cardinal value functions. Int. Trans. Oper. Res. 1994, 1, 489-500. [CrossRef]

73. Bana e Costa, C.A.; Ensslin, L.; Corrêa, E.C.; Vansnick, J.-C. Decision support systems in action: Integrated application in a multicriteria decision aid process. Eur. J. Oper. Res. 1999, 113, 315-335. [CrossRef]

74. Bana e Costa, C.A.; Corrêa, É.C.; De Corte, J.-M.; Vansnick, J.-C. Facilitating bid evaluation in public call for tenders: A socio-technical approach. Omega 2002, 30, 227-242. [CrossRef]

75. Saaty, T.L. Multicriteria Decision Making: The Analytic Hierarchy Process; RWS Publications: Pittsburgh, PA, USA, 1992.

76. Voogd, H. Multicriteria Evaluation with Mixed Qualitative and Quantitative Data. Environ. Plan. Bull. 1982, 9, 221-236. [CrossRef]

77. Voogd, H. Multicriteria Evaluation for Urban and Regional Planning; Pion: Paris, France, 1983.

78. Alinezhad, A.; Khalili, J. EVAMIX Method. In New Methods and Applications in Multiple Attribute Decision Making (MADM); International Series in Operations Research \& Management Science (Volume 277); Springer: Cham, Switzerland, 2019.

79. Martel, J.M.; Matarazzo, B. Other Outranking Approaches. In Multiple Criteria Decision Analysis: State of the Art Surveys; Salvatore, F.J., Ehrgott, G.M., Eds.; Springer: New York, NY, USA, 2005; pp. 197-262.

80. Chatterjee, P.; Stević, Ž. A two-phase fuzzy AHP-fuzzy TOPSIS model for supplier evaluation in manufacturing environment. Oper. Res. Eng. Sci. Theory Appl. 2019, 2, 72-90. [CrossRef]

81. Hassanpour, M.; Pamucar, D. Evaluation of Iranian household appliance industries using MCDM models. Oper. Res. Eng. Sci. Theory Appl. 2019, 2, 1-25. [CrossRef]

82. Popovic, M.; Kuzmanović, M.; Savić, G. A comparative empirical study of Analytic Hierarchy Process and Conjoint analysis: Literature review. Decis. Mak. Appl. Manag. Eng. 2018, 1, 153-163. [CrossRef]

83. Creswell, J.W. Research Design: Qualitative, Quantitative, and Mixed Methods Approaches, 2nd ed.; Sage: Thousand Oaks, CA, USA, 2003.

84. Tashakkori, A.; Teddlie, C. Mixed Methodology: Combining Qualitative and Quantitative Approaches; Sage: Thousand Oaks, CA, USA, 1998.

85. Herwijnen, M.V.; Janssen, R. DEFINITE, A support system for decisions on a finite set of alternatives; Springer: Dordrecht, The Netherlands, 1995.

86. Lo Curzio, M.; Caruso, V.; D'Angelo, M. La Fortificazione Permanente dello Stretto di Messina: Storia, Conservazione e Restauro di un Patrimonio Architettonico e Ambientale; EDAS: Leonia, NJ, USA, 2006.

87. United Nations Educational, Scientific and Cultural Organization. Recommendation on the Historic Urban Landscape, Including a Glossary of Definitions. Available online: https://www.portal.unesco.org (accessed on 10 November 2011).

88. Della Spina, L. Integrated Evaluation and Multi-methodological Approaches for the Enhancement of the Cultural Landscape. In Computational Science and Its Applications - ICCSA 2017; Springer: Cham, Switzerland, 2017; Lecture Notes in Computer Science; Volume 10404. [CrossRef]

89. Nocca, F. Il ruolo del patrimonio culturale nello sviluppo sostenibile: Indicatori multidimensionali come strumento decisionale. Sostenibilità 2017, 9, 1882.

90. Dias, L.C.; Antunes, C.H.; Dantas, G.; de Castro, N.; Zamboni, L. A multi-criteria approach to sort and rank policies based on Delphi qualitative assessments and ELECTRE TRI: The case of smart grids in Brazil. Omega 2018, 76, 100-111. [CrossRef]

91. Antoniucci, V.; Marella, G. The influence of building typology on the economic feasibility of urban developments. Int. J. Appl. Eng. Res. 2017, 12, 4946-4954.

92. Augusto, M.; Lisboa, J.; Yasin, M.; Figueira, J.R. Benchmarking in a multiple criteria performance context: An application and a conceptual framework. Eur. J. Oper. Res. 2008, 184, 244-254. [CrossRef] 
93. Della Spina, L. The Integrated Evaluation as a Driving Tool for Cultural-Heritage Enhancement Strategies. In Smart and Sustainable Planning for Cities and Regions. SSPCR 2017. Green Energy and Technology; Bisello, A., Vettorato, D., Laconte, P., Costa, S., Eds.; Springer: Berlin, Germany, 2018; pp. 1-11. [CrossRef]

94. Bottero, M.; D'Alpaos, C.; Oppio, A. Ranking of adaptive reuse strategies for abandoned industrial heritage in vulnerable contexts: A multiple criteria decision aiding approach. Sustainability 2019, 11, 785. [CrossRef]

95. Calabrò, F.; Della Spina, L. The Public-Private Partnership for the Enhancement of Unused Public Buildings: An Experimental Model of Economic Feasibility Project. Sustainability 2019, 11, 5662. [CrossRef]

96. Calabrò, F.; Della Spina, L. The Projects' Economic Feasibility within Strategic Planning, Integrated Planning, Cultural Planning and Management Plans. An Experimental Model for the Valorisation of Public Buildings in Public-Private Partnerships. LaborEst 2018, 16 IS, 1-40.

97. Carbonara, S. Il recupero dell'edilizia privata nell'Abruzzo post-sisma: Un'analisi delle procedure di stima. Territorio 2014. [CrossRef]

98. Carbonara, S. The effect of infrastructural works on urban property values: The asse attrezzato in pescara, italy. In Computational Science and Its Applications - ICCSA 2012; Springer: Berlin/Heidelberg, Germany, 2012; pp. 128-143.

99. Carbonara, S.; Stefano, D. An Operational Protocol for the Valorisation of Public Real Estate Assets in Italy. Sustainability 2020, 12, 732. [CrossRef]

(C) 2020 by the author. Licensee MDPI, Basel, Switzerland. This article is an open access article distributed under the terms and conditions of the Creative Commons Attribution (CC BY) license (http://creativecommons.org/licenses/by/4.0/). 